\title{
Blurring the Boundaries between History and Fiction in Khoury's Gate of the Sun and Ashour's The Woman from Tantoura
}

\section{Zainab Saeed El-Mansi*}

The central question of the Palestinian problem could be drawn from Achille Mbembe's question, on the broader historical conceptualisation of colonisation, "who does the earth belong to?" Mbembe's question can be altered to: "who does Palestine belong to?" This question is contested by the Palestinians and the settler colonial Zionists long before the 1948 Palestinian Nakba. Since 1948 and beyond, the Zionist narrative has embarked on a mission of Palestinian memoricide (Pappé 2006, 3). To mention but one example of this cultural and historical crime, the Zionist atrocities during 1948 have been denied or at best delegitimised (Beinin 2005,11). This is not surprising in colonial contexts. Hayden White explains that the dominating powerful groups "claim the authority to decide who or what is to be admitted to history" $(2008,9)$; so far, the dominating group is the Zionist Israeli one. In addition to denying/delegitimising the Nakba, the hegemonizing Zionist grand narrative propagates several myths around it. Ironically enough, the Palestinian Nakba did not find its due representation in the Palestinian/Arab mainstream narrative. Such a narrative has always been politically driven and traditionally dominated by the male élite members of the Palestinian society (Issa 2005, 180). Over and above, the Palestinian/Arab mainstream has been a collective narrative which, though the myriad merits of this type of narrative, disregards the voices of the marginalised, like the fellahin [peasants], women, refugees, camp residents and poor uneducated Palestinians.

Endeavouring to write a counter-hegemonic Nakba narrative, several literary figures and historians on the Palestinian/Arab side, ,such as are Elias Khoury, Radwa Ashour, Nur Masalha, Walid Khalidi, and Nafez Nazzal, and a few on the Israeli side, such as Ilan Pappé and Theodor Katz, were interested in narrating idiosyncratic Nakba experiences. Khoury's Gate of the Sun (1998) and Ashour's The Woman from Tantoura (2010) are exemplary literary works which represent historical Nakba experiences through the literary narrative of the fall of Ayn al-Zaytun (Safad District) and Tantoura (Haifa District) respectively.

\footnotetext{
* Lecturer in English and Comparative Literature, The British University in Egypt. Cairo Studies in English 2021(1): https://cse.journals.ekb.eg/
} 
Thus, this paper seeks to analyse how these literary texts intermingle historical and fictional elements of the Nakba to simultaneously refute the Zionist grand narrative and defy the Palestinian/Arab mainstream narrative.

Since the Nakba is a calamity that found expression in history and literature, new historicism is a literary theory of relevance here. New historicism is often linked to the publication of Stephen Greenblatt's Renaissance Self-Fashioning in 1982 (Hall 2001, 301). As Harold Aram Veeser argues in the introduction of his book The New Historicism, this theory "has given scholars new opportunities to cross the boundaries separating history, anthropology, art, politics, literature, and economics. It has struck down the doctrine of non-interference that forbade humanists to intrude on questions of politics, power, indeed on all matters that deeply affect people's practical lives" (1989, ix). Hence, it gives the critic a chance to investigate the relation between the literary text in its historical and cultural contexts. Further, power relation is crucial when it comes to discussing history and literature of the Nakba. Michel Foucault, who is a great influence on new historicism, illustrates that knowledge "induces effects of power" (1980, 52). Accordingly, falsified records of the Nakba that are intrinsic to the hegemonising Zionist exert power over the Palestinian/Arab petits récits; thus, rendering the latter either annihilated, ridiculed or at best marginalised. The two literary texts of concern here emphasise the importance of the Palestinian petits récits vis-à-vis the Zionist grand narrative; thus, these fictional works have a role in the cultural power struggle between the dominating narrative and the marginalised one.

Closely related to the power relations that new historicism investigates is the postmodern approach to literary texts. Tackling the Zionist grand narrative and the Palestinian/Arab petits récits necessitates postmodern tools of analysis. Though novels analysed in this paper rely on historical texts, their writers use postmodern techniques to deconstruct and question the Zionist grand narrative and the Palestinian/Arab mainstream narrative respectively. Jean-François Lyotard (1924-1998) defines postmodernism as the "incredulity toward metanarratives" (1993, xxiv). He explains that metanarratives/grand narratives are presented by a hegemonizing system as master narratives and are also perceived as the absolute truth; thus, they must be criticised (1993, 60). Accordingly, this paper analyses how Gate of the Sun and The Woman from Tantoura criticise the Zionist grand narrative as a representative of the sole truth of 1948 and attempt to deconstruct concepts of this narrative. One of the features of postmodern novels is that this type of literary work implies that "history itself depends on conventions of narrative, language, and ideology in order to 
represent an account of "what really happened"' (Mazurek 2002, 29); this is what the two literary works analysed here expose. The two novels refute two of the core myths propagated by the Zionist grand narrative, namely weak David (the Jews) slaying mighty Goliath (the Arabs) ${ }^{1}$ and the Zionists pleaded the Palestinians to stay in Palestine in the wake of the Nakba, but the Palestinians left after blanket orders of their Arab leaders (Flapan 1987, 187, 81). This is in addition to disputing the famous Zionist slogan: "a land without a people for a people without land"2 which the Zionist grand narrative holds sacred.

Deconstructing the Zionist myths, Gate of the Sun and The Woman from Tantoura blur the boundaries between history and fiction; such blurring is a basic feature of what the Canadian literary theorist Linda Hutcheon calls Historiographic metafiction. Unlike the historical fiction, historiographic metafiction is concerned with rewriting the past in history and fiction; it "plays upon the truth and lies of historical record" (Hutcheon2000, 114). Hutcheon contends that " $[\mathrm{h}]$ istoriographic metafiction refutes the natural or common-sense methods of distinguishing between historical fact or fiction. It refuses the view that only history has a truth claim, both by questioning the ground of that claim in historiography and by asserting that both history and fiction are discourses, human constructs, signifying systems, and both derive their major claim to truth from that identity" $(2000,93)$. Another feature of historiographic metafiction is its protagonists which typically suit the Palestinian characters. These novels' protagonists are marginalised and ex-centric ones who present multiple points of view. Hutcheon believes that both the historian and the writer select certain historical events and call them facts by virtue of giving them a certain meaning (Hutcheon 2005, 55-6).

With the advent of post-modern theories, doubt was cast regarding the validity of recorded history as the only medium by which people recover and construct the past $(2005,179)$. Consequently, some questions seem to rise and are certainly valid for the sake of this paper; among them are: "Who makes history? What about the experience and the accounts of the 'illiterate', the 'marginal', the 'colonised' and the 'oppressed'?" $(2005,179)$. The Palestinian historians and Arab literary authors of concern here seem to adopt the same approach towards the Palestinian mainstream narrative of the Nakba on the one hand and seek to deconstruct the concepts found in the Zionist grand narrative on the other. Gate of the Sun and The Woman from Tantoura attempt to answer the previously mentioned questions and represent petits récits as an alternative representation of the Nakba. 


\section{The Need for Palestinian/Arab Counter-Hegemonic Nakba Narratives}

There are a number of challenges that would obstruct writing Nakba counterhegemonic narratives. As mentioned earlier, the Zionist grand narrative does not stop at propagating lies about its foundation; it extends to marginalise and delegitimise the Palestinian/Arab narrative as well. In fact, the Palestinians' situation is a difficult one; they have been "pitted against an undeniably superior antagonist whose consciousness of himself and of the Palestinian is exactly, positionally, superior" $(1992,15)$. Moreover, as the late Edward Said brilliantly observed, the Palestinian has become a nonperson as opposed to the Zionist who is the only person in Palestine (37) that is worth mentioning, narrating about and representing. As a result, the Nakba counter-hegemonic narratives have always attempted to deconstruct the Zionist grand narrative and reconstruct genuine Palestinian narratives of 1948. In order to deconstruct the Zionist grand narrative, El-Messiri suggests recalling the historical and present occupation facts and comparing them to the Zionist claims $(2003,59)$; this is part of what the literary works analysed here do.

To deconstruct the Zionist grand narrative and avoid the pitfalls of the Nakba collective narrative, an interest in narrating the Nakba from the viewpoint of its witnesses started to rise. Masalha believes that recently "historians have been paying increasing attention to the idea of 'social history from below' - or 'from the ground up', thereby giving more space to the voices and perspective of refugees and women ... and incorporating extensive refugee oral testimony and interviews" $(2012,219)$. Relying on oral history began in 1979 by the geographer Kamal Abdel Fattah and the anthropologist Sharif Kanaana of Birzeit University (Masalha 2008, 135). The Palestinian oral history is of pivotal importance as it represents a "decision as to whether to document any history at all" (Masalha 2005, 6); hence, it has further significance in the cultural power struggle of the Palestinian-Zionist context. In fact, relying on oral history is a way to give voice to the voiceless amidst denial of the dominating Zionist narrative and the collective male dominated and élitist Palestinian/Arab narrative.

\section{The Literary Representation of the Nakba}

Gate of the Sun and The Woman from Tantoura narrate the Nakba from the ground-up. The importance of these two Arab literary narratives lies in representing what could be called "subjective history"; this history finds "beneath events, another, more serious, more secret, more fundamental history [and] closer to the origin" (Foucault 2004, 136). From this perspective, the two Arab writers attempt to rewrite and "correct" the Nakba narratives. Though 
Khoury and Ashour are not Palestinians, they contributed extensively to the Palestinian cause.

Khoury is a Lebanese novelist, critic, academic, editor and commentator who grew up with Palestinian refugees that flocked to Lebanon in the year of his birth. When he was nineteen years old, Khoury "travelled alone to Amman to join the Palestinian resistance after Israel occupied the West Bank and Gaza" (MannesAbbott 2005). He joined Fatah in the late 1960s and worked "as a researcher at the Palestine Research Centre in Beirut" (Masalha 2012, 226). Khoury has written extensively about the Palestinian issues; whether fictional works, or newspaper articles or academic ones.

In order to write Gate of the Sun, Khoury relied on stories narrated by the Palestinians that he worked with and those of refugee camps (Mannes-Abbott 2005). The novel narrates, in a non-linear manner, the on-going Nakba through three generations. Set in the 1990s, the novel foregrounds the experiences of Palestinian fellahin who became poor refugees in the Shatila refugee camp in Lebanon. It presents the Palestinians' plight throughout the 1948 Nakba, the Lebanese civil war, the Sabra and Shatila massacre and beyond. The narrative eloquently but irritatingly shifts between many narrators; however, the one that is paradoxically dominant and marginalised is Khaleel of Jil Al-Nakba [Generation of the Nakba]. ${ }^{3}$ The novel was praised by Said, won the Prize for Palestine and was adopted into a film by the Egyptian director Yousry Nasrallah (Jaggi 2005). It was translated into many languages, including Hebrew in 2002 (Goldberg 2015, 336).

The other literary figure here is Radwa Ashour. Ashour, a prominent Egyptian novelist, critic and university professor, advocated the Palestinian cause and contributed to the founding of the National Committee Against Zionism in Egyptian Universities. She published eight novels, two collections of short stories, five literary criticism books and autobiographies. She co-edited a fourvolume work on Arab women writers in 2004. She also translated Mourid Barghouti's "Midnight and Other Poems" (2008). Ashour won the top prize at Arab Women's Book Fair in 1995 for the Granada Trilogy. This is in addition to winning "several awards outside Egypt, including one of Greece's highest literary honors, the Constantine Cavafy Prize for Literature, in 2007, and the Tarquinia Cardarelli International Criticism Prize from Italy in 2009" (El-Qasas and Rabea 2014). The acclaimed Egyptian critic and novelist Salwa Bakr maintains that Ashour "was among those Egyptian writers who followed a school of thought in literature that was concerned with communicating the troubles of ordinary people in their works, thereby preserving Egyptian and also 
Arab identity" (as cited in El-Qasas and Rabea 2014). Bakr adds that Ashour "was one of those writers who sought to remind the Arab world of Palestinian identity, which is made very clear in her novel, Al-Tantouria" (as cited in ElQasas and Rabea 2014).

The experiences of Palestinian women constitute a crucial component of the counter-hegemonic Nakba narratives. One of these distinguished experiences is manifested in The Woman from Tantoura where the iterability of the Nakba from a woman's viewpoint is foregrounded. The dominating voice is that of the Palestinian woman Ruqayya. Belonging to Jil Filastin [Palestine Generation], ${ }^{4}$ Ruqayya is a strong woman who comes from a relatively rich Palestinian family. Belonging to a family as such saves her from being stranded in a refugee camp like Khaleel and the other characters of Khoury's novel. However, Ruqayya shares with Khoury's characters the Palestinian identity which makes her and her offspring suffer from being treated as aliens in their host country: Lebanon; then moving between Egypt and the Gulf. Ashour deconstructs many aspects of the Zionist grand narrative and Palestinian nationalist narrative. The reader ultimately decodes Ashour's message as she/he negotiates the writer's position: the Palestinians resisted the Zionist coloniser as much as they could, Tantoura's people were well aware of the coming invasion and the Palestinians are not merely victims.

The narratives of Khaleel and Ruqayya are individual ones which attempt to prevent the individual experiences of the Nakba from being silenced or annihilated and change the Palestinian passive victim image prevalent in the Zionist grand narrative and the Palestinian/Arab mainstream narrative (Abdel Jawad 2006, 88; Abu-Lughud and Sa'di 2007, 8).The identities of Khaleel, Ruqayya and almost all the Palestinian characters in the two novels are socially and politically constructed because their lives are determined by the Nakba. Indeed, the Nakba is paradoxically the starting and ending point of their lives. What Khoury tries to represent is an individual story of the fedayee ${ }^{5}$ Yunis AlAsady which intermingles with other individual Palestinian Nakba stories. Likewise, Ashour represents the individual story of the female Palestinian refugee Ruqayya that combines stories of other refugees. These personal narratives are entangled with the fall of some Palestinian villages and the prolonged Nakba that the Palestinians have gone through. 


\section{Intermingling History with Fiction}

Gate of the Sun narrates the fall of several villages in Al-Jaleel. For the purpose of this paper, however, the emphasis will be on Ayn al-Zaytun ${ }^{6}$ (Safad District). The Woman from Tantoura mainly narrates the fall of the Palestinian coastal village Al-Tantoura ${ }^{7}$ (Haifa District). Historical information about these villages was brilliantly documented, among other villages, in Khalidi's book All that Remains: The Palestinian Villages Occupied and Depopulated by Israel in 1948; however, the book lacks the testimonies of surviving Palestinians which the two novels here foreground.

After the constant struggle and sometimes resistance to narrate the Nakba, Khaleel and Ruqayya manage to represent images of the shattering Nakba experience. While Khaleel fails until the end to narrate a coherent story, Ruqayya succeeds. Khaleel is an unprivileged narrator in comparison to Ruqayya. He lives in the Shatila refugee camp which makes him among the poorest refugees. Khaleel, which means a friend in Arabic, ("Ta'areef wa Ma'na Khaleel Fi Mojam Al-Ma'any Al-Jame" 2017) imprisons himself, throughout the narrative, in the makeshift hospital Al-Jaleel in front of coma-stricken Yunis. $\mathrm{He}$ is a companion of death; he witnessed the Sabra and Shatila massacre and remains by the death bed of Yunis throughout the course of the narrative. On the other hand, Ruqayya has lived in her own house, which though constantly changing, is not a refugee camp. She is not as poor as Khaleel, she is married for a certain period of time, and has children who represent hope and future. All these characteristics prepare Ruqayya to be relatively capable of dominating her past experience and reproducing it through what could be called a coherent but entangled narrative.

The Israeli New Historians' historical narratives and the Palestinian ones documented the fall of Ayn El Zaytun. Historically speaking, Ayn El Zaytun was important for the Zionists by virtue of being in a strategic position, "a mile west of Safad" (Pappé 2006, 111). The Israeli New Historian Pappé documents that the relationship between the Palestinians and the settlers grew tense by the end of the British Mandate; thus, operation "Broom" "provided a chance for the Hagana's elite unit, the Palmach, not only to cleanse the village ... on 2 May 1948, but also to settle 'old accounts', namely the hostility with which the Palestinian villagers had viewed and received the settlers" (Pappé 2006, 111). The Palestinian historical narrative thoroughly explains that on 2 May 1948 "Palmach unit, with mules loaded with ammunition, advanced towards the village of Ein ez Zeitun by way of Tall al Durraiyat, which overlooks the village to the north from the top of a hill. Palmach soldiers rolled barrels filled with 
explosives down the hill to the village and threw hand grenades, killing and injuring many of the villagers" (as cited in Nazzal 1978, 34-5).

On the literary level, the historical narratives are blurred with the fictive ones. Deconstructing the Zionist myth of the Palestinians willingly leaving their villages, Khaleel's narration echoes Nazzal's historical documentation: “[o]n the night of 1 May 1948, a Palmach unit with mules carrying ammunition advanced on Ein El Zeitoun via the hill of El Dweirat, which overlooks the village from the north, and from the hill the Palmach men rolled barrels of explosives down onto the village" (Khoury 2005, 162). Here, like historiographic metafiction, there is no neat dividing line between literature and history (Hutcheon 2000,136). Moreover, the narrative blends historical reality with fictional representation and individualised exodus experiences. Khaleel continues to coma-stricken Yunis:

Umm Sileiman said, weeping, that they'd killed your father. You reached the olive grove and saw their forlorn wandering ghosts moving about aimlessly. You grabbed Umm Sileiman by the shoulder, but she didn't stop. She kept walking and you kept trying to catch up with her. (Khoury 2005, 162)

The narrative then moves on to deconstruct the David slaying Goliath myth which entails the Zionist claim of self-restraint [havlaga]. Khaleel quotes one of the fellahin's testimonies that refers to Yusuf Ahmad Hajjar's incident. The same incident is also recorded in Pappé's The Ethnic Cleansing of Palestine:

In one incident $[\ldots]$ one of the villagers, Yusuf Ahmad Hajjar, told his captors that he, like the others, had surrendered and thus 'expected to be treated humanely'. The Palmach commander slapped him in the face and then ordered him, by way of punishment, to pick thirty-seven teenagers at random. While the rest of the villagers were forced into the storage room of the village mosque, the teenagers were shot with their hands tied behind their backs. (2006, 111-2)

On the literary level, Khaleel starts quoting one of the fellahin's testimonies:

We were standing ... and they were firing over our heads. We started to crouch down, some of us kneeling, some squatting, some lying flat on the ground. Then Yusif Ibraheem El Hajjar stood up [...] 
[and] went to the soldier, bearing the seventy-five years of his life on the shoulders of his huge body [and said] We surrender. Our village has fallen, and our men are defeated, and we surrender and expect to be treated humanely. Pay attention now. We are captives, and you have to treat us the way captured civilians are treated in wartime. We're not begging for your sympathy. We're requesting it and will repay it. If you treat us well, we'll repay your good deed with even better ones. Tomorrow, as you know, Arab armies will enter Palestine, and we'll defeat you, and then we'll treat you as you treat us today. It would be better for you that we come to an understanding. I declare that I have said what I must, as God is my witness. (Khoury 2005, 162-164)

The same historical incident is eloquently written in a fictive wrap. Hajjar, unlike heroes of historical novels, is not a grand historical figure, or a type that readers would follow. He is an old fellah who is usually ignored in élitist narratives, but here his speech is foregrounded. Perhaps the exact words that he said are fictional; for example, that there is no mention of the ALA [Arab Liberation Army] in the original testimony at all. This can be read in terms of the postmodernist stand that confronts "the paradoxes of fictive/historical" (Hutcheon 2000, 106), suggesting that the Nakba is both fictional due to its unbelievable nature and real as a historical event with glaring impacts until now. Through the surrender of Ayn El Zaytun's Palestinians, the David slaying Goliath myth is deconstructed. The previous quote also deconstructs all the claims of self-restraint that were mentioned in, for example, Netanel Lorch's The Edge of the Sword. What El-Hajjar ends his speech with is ironical; the ALA did nothing to save the Palestinians or Palestine which further deconstructs the David slaying Goliath myth.

Khoury's narrative moves on to defy the Palestinian/Arab mainstream narrative. Khaleel is rather sceptical of what the Palestinian nationalist narrative holds sacred: national figures and the fedayee image. It centralises, instead, a down to earth marginalised Palestinian image. In a near trial scene, Khaleel, a victim of the fall of Palestine, holds Yunis accountable for the former's misery. It is as if Khaleel or the Palestinian refugees question the Fedayeen that were supposed to defend them and save the village: "Where were you on 1 May?" (Khoury 2005, 162) What the narrative foregrounds here is the fedayee Yunis's passivity. Khaleel narrates the fall of the village after its end which simultaneously happens with Yunis's arrival to his village signifying the latter's 
futile attempt to save his village. Addressing Yunis, Khaleel narrates: "[w]hen you returned to your village carrying your English rifle, you saw Palmach men everywhere and you didn't do a thing. ... You took a bit of iron, heated it in the fire and scratched the date on your left wrist. Then you ran off to the fields" (Khoury 2005, 162). Yunis's reaction symbolises Jil Filastin's idealisation of and imprisonment in the past; thus, their inability to liberate themselves or their country. From this perspective, Khoury deviates from the traditional narratives by not blaming the ALA but the Palestinians for the fall of Palestine. Thus, the struggle, unlike its portrayal in the Zionist grand narrative, is between the Palestinians and the Zionist coloniser.

As the fall of Ayn al-Zaytun was represented in history and fiction, Tantoura's calamity was also represented in both fields. Though no massacre is necessary or legitimate, the Tantoura massacre was avoidable; such a horrendous action, to say the least, was perpetrated after the surrender of its citizens (Esmeir 2007, 231). Historically speaking, one week after the declaration of the new colonial state, Tantoura was attacked. Exactly on 22-23 May at night, the Alexandaroni Brigade: the Haganah's Thirty-Third Battalion, carried on the mission of attacking and occupying the village. The village, one of the largest coastal ones, was within the area assigned to the Zionists by the UN Partition Resolution ("The Tantura Massacre, 22-23 May 1948" 2001, 5). Pappé continues the "offensive came from all four flanks. This was uncommon; the brigade usually closed in on villages from three flanks, tactically creating an 'open gate' on the fourth flank through which they could drive the people out. Lack of coordination meant that the Jewish troops had fully encircled the village and consequently found themselves with a very large number of villagers on their hands" $(2006,133)$.

The Zionist grand narrative denies, among other massacres, that such a massacre took place, but in 1999 Katz's master's thesis exposed this lie by including a special focus on Tantoura's massacre (Pappé 2006,136). Though his thesis received exceptionally high grades, Katz was attacked and sued for libel by the Alexandaroni Brigade veteran's association for fabricating evidence (Esmeir 2007, 231). Katz's thesis relied on non-official narratives by interviewing Alexandaroni veterans and Palestinian refugees who witnessed the massacre in Tantoura. The thesis reveals that after the fall of Tantoura, old men, children and women were deported by members of the Alexandaroni Brigade to Furaydis; a nearby village of Tantoura. The Alexandaroni Brigade members' brutality did not halt at that point; they massacred around 250 men and imprisoned the rest (Esmeir 2007, 231). 
On the literary level, witnessing the Nakba, Ruqayya demonstrates in minute detail her individual hijra [exodus] experience from Tantoura. Ashour blurs the boundaries between history and fiction to deconstruct the famous Zionist slogan and the myth that the Palestinians willingly left their country. Ruqayya's narrative reveals the domestic aspects of women's Nakba narratives which Khaleel's narrative lacks. She remembers her mother closing their house gate, locking it and giving orders that reflect her firm belief that they will come back; her mother urges her to: "[p]ut out fodder that will last two or three weeks" (Ashour 2014, 44). Ashour directly relies on oral history. After a few hours, the Zionists attacked; Ruqayya narrates: "[t]hey drove us to the beach and divided us into two groups, the men on one side and the women and children and some old men on the other side" (Ashour 2014, 46). This part is found in the testimony of Najiah Abu Amr from Tantoura; she says: "All the men and the women, and they were separated. Women on one side, men on the other. And then they took us near the graveyard, brought buses, and took the women and children out of the village" (as cited in Pappé 2001, 36). Ruqayya continues "They spoke to us in Arabic and began to search us, one after the other, taking any money or jewellery they found on us and putting it in a helmet" (Ashour 2014, 46). This is again found in Abu Amr's testimony: "They took a lot of gold from the women" (as cited in Pappé 2001, 36). Emphasising the loss of gold signifies women's "material and symbolic losses comparable to those of the men in the Nakba" (Humphries and Khalili 2007, 215). Ruqayya further continues: "[o]n the way I saw three corpses and then two more, none of which I recognized" (Ashour 2014, 47). Similarly, on the way Abu Amr saw "Corpses of the dead" (as cited in Pappé 2001, 36); she, like Ruqayya, did not witness the massacre. All this signifies the brutality of the Zionists and th way the Palestinians of Tantoura were forced to leave their village.

However, historically, the Tantoura massacre was stopped by some Zionists from the neighbouring settlement Zikhron Yaakov. As Ali Abd al-Rahman Dekansh (Abu Fihmi), narrates:

Then came three people from Zichron Yaacov who said, "Why are you doing this? Why are you killing [these] people?" They [the soldiers] said to them, "These are Iraqis and Syrians." They [the people from Zichron] said, "These are the people of Tantura, and in the summer we visit them. They give us their houses, and they sleep outside. We spend the summer here. Why are you doing this?" So 
they made us sit [and stopped the shooting]. (as cited in Pappé 2001, 35)

In Ruqayya's narrative, Zikhron Yaakov is mentioned in other ways. She mentions Zikhron Yaakov twice: once in relation to its prison during the expulsion; "They would take a group of men, five or six or seven, and disappear. Were they taking them to the prison in Zikhron Yaakov?" (Ashour 2014, 47). And later after the expulsion from Tantoura only: "After we arrived in alFuraydis some of the boys began to work in Zikhron Yaakov for a few piasters, bringing them back to their mothers, at the end of the day so they could buy bread. Sometimes the Jewish boys from the settlement would harass them, beating them and taking the money" (Ashour 2014, 49). This all signifies a bleak image of the Zionists as colonisers and usurpers of the land. Ashour's choice here suggests that fictional works "constitute their objects of attention; in other words, they decide which events will become facts" (Hutcheon 2000, 122).

Deconstructing the other myth of David slaying Goliath myth and the victimised image of the Palestinians, Ashour, like Khoury, blends history with fiction in relation to the ALA saving Palestine. The novel represents the failure of the ALA to defend Palestine through Ruqayya's uncle Abu Amin's heated argument with his brother, her father Abu Sadeq. These two pillars of Ruqayya's family demonstrate two divergent viewpoints towards resisting the Zionists that were prevalent a few days prior to the fall of Tantoura. One viewpoint sees that the best way to defend Palestine is to remain inside and fight the Zionists with the few sources they have, whereas the other wants to fight the Zionists only after being properly trained and acquiring arms away from the country. Through the conversation between these two brothers, the narrative defies the Zionist grand narrative that claims the following:

The Arab Higher Committee (AHC) and the local National Committees ... actively promoted the depopulation of villages and towns. Many thousands of Arabs - women, children, and old people [...] left, well before battle was joined, as a result of advice and orders from local Arab commanders and officials [...]. Indeed, already months before the war the Arab states and the AHC had endorsed the removal of dependents from active and potential combat zones [...]. There can be no exaggerating the importance of these early, Arab-initiated evacuations in the demoralization, and 
eventual exodus, of the remaining rural and urban populations. (Morris 2004, 589-590)

Morris's clear Zionist ideology holds the Palestinian National Committees, not the Zionists, accountable for the Palestinian "exodus". He implies that it was not ethnic cleansing, but rather people fleeing out of fear of war. He also denies the Palestinians' agency and political awareness during May 1948 and months before it. However, Ashour's narrative deconstructs these claims. While Ruqayya's father was one way or another optimistic, or rather not realistic about the situation at hand, her uncle was the opposite. Abu Amin analyses the situation in light of figures and facts. In this conversation, the ALA did not intervene to save Palestine: "[s]even hundred soldiers of the Jordanian army were near [Haifa] observing events and could not intervene" (Ashour 2014, 32); which is a reflection of the historical narratives of Pappé and Avi Shlaim that state that King Abdullah of Transjordan made a no attack pact with the Zionists (2006, 128; 84). Abu Amin concludes his argument in fury saying: the Zionists "have weapons and the British are with them and they are trained" (Ashour 2014, $32)$; which is the literary representation of what Rosemary Sayigh (2007, 70-1) and Masalha documented in relation to the British helping the Zionists colonise Palestine. Abu Amin's remark is interrupted by the optimistic and unrealistic "[w]e have God with us because we are in the right" (Ashour 2014, 32).

Though Tantoura was a small village and its fellahin knew nothing about fighting, each fellah participated in fending off the Zionists and defending her/his small village. A Glimpse of resisting the Zionist occupation in 1948 is revealed in the observations of young Ruqayya: the families in Tantoura are buying arms, but the arms were already damaged, whereas the Zionists' arms are from different countries. Further, the Palestinians were a group of poorly trained fellahin facing a regular army. It could be deduced that neither the Zionists were weak David, nor the Palestinians or ALA were mighty Goliath. Having Ruqayya's two uncles negotiate the political situation reflects a political awareness and refutes the victim image of the Palestinians.

To sum up, Gate of the Sun and The Woman from Tantoura can be classified as historiographic metafictional narrative works in the Hutcheonian sense, albeit with various degrees. The importance of these literary works lies in representing counter-hegemonic narratives that simultaneously deconstruct and defy the Zionist grand narrative and the Palestinian/Arab mainstream narrative respectively. Relying on oral Nakba narrative and Nakba historical narratives, the literary works of Khoury and Ashour, deconstruct the Zionist myths of David 
slaying Goliath, the Palestinians fleeing their country and the famous Zionist slogan of "a land without a people for a people without land". The two novels emphasise that neither the fellahin of Ayn El Zaytun, nor of Tantoura had enough arms to fight the Zionists. Both villages were invaded at night while its inhabitants were sleeping, and the ALA was absent. The Zionists used explosive barrels against the sleeping fellahin of Ayn El Zaytun and committed a massacre after the surrender of Tantoura's indigenous people. Though being unarmed, the Palestinians of Ayn El Zaytun and Tantoura refused to leave their villages which led to their expulsion. The two Arab literary narratives also defy the Palestinian/Arab mainstream narrative, which was collectively dominated by the male élitist members of the Palestinian society and presented a victim image of the Palestinians of 1948. Gate of the Sun and The Woman from Tantoura reconstruct individual voices of the Palestinians that comprise voices of poor refugees and women. Both works foreground the Palestinians' struggle to fend off the Zionist colonisation, with Ashour's narrative, in particular, reflecting the political awareness of simple Palestinian fellahin at that time. In his insightful definition of mainstream historical writing, White maintains that it "is an ideological weapon with which to double the oppression of already vanquished groups by depriving them of their historical pasts and consequently of their identities as well" (White 2008, 9). Therefore, it is both Khoury's and Ashour's intentions in Gate of the Sun and The Woman from Tantoura, respectively, to represent alternative Nakba narratives which centralise different Palestinian Nakba experiences that have long been marginalised or absent.

\section{Endnotes}

${ }^{1}$ One of the commonly used Biblical stories, by conservative Israelis, is David slaying Goliath. According to the Torah, shepherd weak young David tells the mighty warrior Goliath: "I come to thee in the name of the Lord of hosts, the God of the armies of Israel" (Sam. 17:45), then he attacks and conquers him by the power of God, not with the sword.

${ }^{2}$ This famous Zionist slogan is thought to be formulated by the British author Israel Zangwill (1864-1926). The Palestinian Professor of History Bishara Doumani sees that this slogan entails, "the absence of 'civilized' people, in the same sense that the Americas and Africa were portrayed as virgin territories ready for waves of pioneers" $(2007,15)$. Said explains that this slogan means "to 
cancel and transcend an actual reality - a group of resident Arabs- by means of a future wish - that the land be empty for development by a more deserving power" $(1992,9)$.

${ }^{3} \mathrm{Jil}$ Al-Nakba refers to the Palestinians who were born after the Nakba (George 1996, 245)

${ }^{4}$ Jil Filastin refers to the Palestinians who experienced living in Palestine before the Nakba and were adults at its time (George 1996, 245).

${ }^{5}$ Fedayee is "a member of an Arab commando group operating against Israel". It literally means "one who sacrifices himself" in Arabic ("Fedayee" 2019).

6 'Ayn al-Zaytun's population, that was entirely Muslim, was 820 in 1944-45. There was a mosque and an elementary school inside the village. Olives, grapes and grains were cultivated by the Palestinian villagers; however, all of this was destroyed by the occupation on 3 January 1948 (Khalidi 1992, 437).

${ }^{7}$ Before the Nakba, Tantoura enjoyed two elementary schools: one for girls, which was established in 1937/38, and another for boys that was established around 1889. It also welcomed the travellers in a guest house made in the shape of a square stone building. Its economy depended on agriculture in addition to fishing by virtue of its location (Khalidi 1992, 194). Khalidi adds that by 1931 the number of its houses was 247 and its population was 953; 952 of which were Palestinians and 1 Jewish person (1992, 193). Before 1931, the English Orientalist James Silk Buckingham (1786-1855) makes this observation about Tantoura's population: its "present inhabitants, perhaps five hundred in number, are all Mohammedan, and are governed by a sheikh" $(1992,125)$.

\section{Works Cited}

Abdel Jawad, Saleh. 2006. "The Arab and Palestinian Narrative of the 1948 War." In Israeli and Palestinian Narratives of Conflict: History's Double Helix, edited by Robert I. Rotberg, 72-114. Bloomington: Indiana University Press.

Abu-Lughod, Lila and Ahmad H. Sa'di. 2007. "Introduction: The Claims of Memory." In Nakba: Palestine, 1948, and the Claims of Memory, 1-24. New York: Columbia University Press.

Ashour, Radwa. 2014. The Woman from Tantoura. Translated by Kay Heikkinen. Cairo: The American University in Cairo Press. 
Beinin, Joel. 2005. "Forgetfulness for Memory: The Limits of the New Israeli History." In Institute for Palestine Studies 34, no. 2: 6-23. https://doi.org/10.1525/jps.2005.34.2.006.

Doumani, Bishara B. 2007. "Rediscovering Ottoman Palestine: Writing Palestinians into History." In The Israel/Palestine Question: A Reader, edited by Ilan Pappé, 2nd ed., 11-39. New York: Routledge.

El-Messiri, Abdel Wahab. 2003. Concering the Zionist Terms and Discourse: A في الخطاب والمصطلح الصهيونس: دراسة نظرية وتطبيقية Theoritical and Practical Study Cairo: Dar AL-Shorouk.

El-Qasas, Gamal, Sarah Rabea. 2014. "Radwa Ashour: Between Imagination and Reality." Asharq Al-Awsat, December 3.

http://www.english.aawsat.com/gamal-elqasasandsarahrabea/lifestyleculture/radwa-ashour-between-imagination-and-reality.

Esmeir, Samera. 2007. "Memories of Conquest: Witnessing Death in Tantura." In Nakba: Palestine, 1948, and the Claims of Memory, edited by Ahmad Sa'di and Lila Abu-Lughod, 229-250. New York: Columbia University Press.

"Fedayee". 2019. Merriam-Webster. Last Modified 2019. Accessed June 13, 2019 https://www.merriam-webster.com/dictionary/fedayee.

Flapan, Simha. 1987. The Birth of Israel: Myths and Realities. New York: Pantheon Books.

Foucault, Michel. 2004. Archeology of Knowledge. London: Routledge.

-----. 1980. Power/Knowledge: Selected Interviews and Other Writings 19721977, edited by Colin Gordon. Translated by Colin Gordon, et al. New York: Pantheon Books.

George, Rosemary Marangoly. 1996. The Politics of Home: Postcolonial Relocations and Twentieth-Century Fiction. Cambridge: Cambridge University Press.

Goldberg, Amos. 2015. "Narrative, Testimony, and Trauma." International Journal of Postcolonial Studies 18, no.3: 335-358. https://ezproxy.bue.edu.eg:2063/doi/full/10.1080/1369801X.2015.1042396 Hall, Donald E. 2001. Literary and Cultural Theory: From Basic Principles to Advanced Applications. Boston: Houghton Mifflin Company.

Humphries, Isabelle and Laleh Khalili. 2007. "Gender of Nakba Memory." In Nakba: Palestine, 1948, and the Claims of Memory, edited by Ahmad H. Sa'di and Lila Abu-Lughod, 207-227. New York: Columbia University Press.

Hutcheon, Linda. 2000. A Poetics of Postmodernism: History, Theory, Fiction. New York: Routledge.

-----. 2005. The Politics of Postmodernism. New York: Routledge. 
Issa, Mahmoud. 2005. "The Nakba, Oral History and the Palestinian Peasantry: The Case of Lubya." In Catastrophe Remembered: Palestine, Israel and the Internal Refugees, edited by Nur Masalha, 178-196. London: Zed Books.

Jaggi, Maya. 2005. "Review: Gate of the Sun by Elias Khoury." The Guardian, November 12.

https://www.theguardian.com/books/2005/nov/12/featuresreviews.guardianr eview16.

Khalidi, Walid. 1992. All that Remains: The Palestinian Villages Occupied and Depopulated by Israel in 1948. Washington, D.C.: Institute for Palestine Studies.

Khoury, Elias. 2005. Gate of the Sun. Translated by Humphrey Davies. Wiltshire: Bloomberg.

Lorch, Netanel. 1961. The Edge of the Sword: Israel's War of Independence, 1947-1949. New York: Putman \& Co., Ltd.

Lyotard, Jean-François. 1993. The Postmodern Condition: A Report on Knowledge. Translated by Geoff Bennington and Brian Massumi. Minneapolis: University of Minnesota Press.

Mannes-Abbott, Guy. 2005. "Elias Khoury: Myth and Memory in the Middle East." The Independent, November 18. http://www.independent.co.uk/artsentertainment/books/features/elias-khoury-myth-and-memory-in-themiddle-east-515728.html.

Masalha, Nur.1993. Expulsion of the Palestinians: The Concept of Transfer in Zionist Political Thoughts, 1882-1948. New York: The Institute of Palestine Studies.

-----. 2005. "Introduction." Catastrophe Remembered: Palestine, Israel and the Internal Refugees, edited by Nur Masalha, 1-20. London: Zed Books.

-----. 2008. "Remembering the Palestinian Nakba: Commemoration, Oral History, and Narratives of Memory." Holy Land Studies 7, no. 2: 123-156. https://doi.org/10.3366/E147494750800019X

-----. 2012. The Palestine Nakba: Decolonising History, Narrating the Subaltern, Reclaiming Memory. London: Zed Books.

Mazurek, Raymond A.2002. "Metafiction, the Historical Novel, and Coover's The Public Burning." Critique: Studies in Contemporary Fiction 23, no. 3: 29-42. https://doi.org/10.1080/00111619.1982.9933783

Mbembe, Achille. 2020. "Out of the Dark Night." Uploaded on October 24. YouTube Video, 1:44:09 min.

https://www.youtube.com/watch?v=sWHYQ6CqP20\&t=2559s 
Morris, Benny. 2004. The Birth of the Palestinian Refugee Problem Revisited. Cambridge: Cambridge University Press.

Nazzal, Nafez. 1978. The Palestinian Exodus from Galilee 1948. Beirut: The Institute for Palestine Studies.

Pappé, Ilan. 2006. The Ethnic Cleansing of Palestine. England: Oneworld Publications Limited

-----. 2001. "The Tantura Case in Israel: The Katz Research and Trial." Journal of Palestine Studies 30, no. 3: 19-39.

http://www.jstor.org/stable/10.1525/jps.2001.30.3.19.

Said, Edward. 1992. The Question of Palestine. New York: Vintage Books.

Sayigh, Rosemary. 2007. The Palestinians from Peasants to Revolutionaries. London: Zed Books.

Shlaim, Avi. 2008. "Israel and the Arab coalition in 1948." In The War for Palestine: Rewriting the History of 1948, edited by Eugene L. Rogan and Avi Shlaim, 79-103. New York: Cambridge University Press.

“Ta'areef wa Ma'na Khaleel Fi Mo’jam Al-Ma'any Al-Jame.” 2017. ("Definition of the Word Khaleel"). Al-Maany.

www.almaany.com/ar/dict/ar-ar/\%D8\%AE\%D9\%84\%D9\%8A\%D9\%84/.

The Jewish Bible. 2009. Indore: Varda Books.

“The Tantura Massacre, 22-23 May 1948."2001.Journal of Palestine Studies 30, no. 3: 5-18. http://www.jstor.org/stable/10.1525/jps.2001.30.3.5.

White, Hayden. 2008. "The Historical Event." A Journal of Feminist Cultural Studies 19, no. 2: 9-34. https://doi.org/10.1215/10407391-2008-002

Veeser, Harold Aram. 1989. "Introduction". The New Historicism, edited by Harold Aram Veeser, ix-xvi. London: Routledge. 